\title{
The Impact of Accounting Harmonization on Financial Statements Quality in Serbia
}

\author{
Danijela Anđelkovićn ${ }^{*}$ | Danijela Zubac ${ }^{2}$ \\ 1 University “Union Union - Nikola Tesla“, Belgrade, Faculty of Entrepreneurial Business, Belgrade, Serbia \\ ${ }^{2}$ Higher Technical Professional School Zvecan, Serbia
}

\begin{abstract}
The general process of the world market globalisation and the great influence of international financial organisations, especially the IMF and the World Bank, caused the need for standardisation and harmonisation of financial statements of the participants involved in international economics and trade. In this process, in the Republic of Serbia, the International Accounting Standards Board (IASB) and the IASB.S project for IAS/IFRS implementation have a crucial role. By adopting the International Financial Reporting Standards - IFRSs (including International Accounting Standards IASs), financial statements prepared in Serbia may be comparable with financial statements in other countries. Starting from this, the main goal of the research is to indicate whether the financial statements in Serbia based on the IASB project can be comparable with financial statements in other countries, and on this basis can they satisfy the needs of external users of information (investors, creditors and others). In doing so, it points to the experience in the Republic of Serbia, the accounting practice and experiences of other countries, above all members of the European Union. The results of the research show that, in addition to the IAS/IFRS, the US generally accepted accounting principles (GAAPs) and the Directive 34 of the European Union represent the key segments of professional regulation contributing to greater accounting harmonisation, and on this basis, the higher quality of financial reporting. Most countries that have national accounting regulations align the accounting rules in the most important issues with those regulations.
\end{abstract}

Key words: accounting standards, harmonisation, IFRS, IASB

JEL Classification: M41, M48, G15

\section{INTRODUCTION}

Financial statements represent an important and reliable basis for the management, and in particular for the external users, to acquire information about enterprises from the business environment, both by branches and by the areas to which they belong, which is fundamental for making strategic decisions. The information power of the statement is the most important given that based on it, by applying the relevant analysis, conclusions on the enterprise's yield, assets and financial position are made. Comparable and transparent financial statements represent a basis for deeper and more liquid financial markets, for strengthening investors' confidence, and thus to overall financial stability. All this, in turn, contributes to the construction of a modern market structure in the function of ensuring greater competitiveness among enterprises.

Several countries, including the Republic of Serbia, has accepted the International Accounting Standards/International Financial Reporting Standards (IAS/IFRS) as the single financial

\footnotetext{
${ }^{*}$ Corresponding author, e-mail: andjelkodani@gmail.com
} 
reporting framework for all enterprises, taking into account, to a certain extent, formal specificities applicable to small and medium-sized enterprises. Unlike Serbia, most other countries that have their national accounting regulations align their accounting rules with their accounting practices, with the IAS/IFRS, but also with other standards, such as the Directive 34 of the European Union. In the context of the quality and interest of users, the International Federation of Accountants (IFAC) has established specific accounting rules and principles, and thus greatly harmonised the accounting, i.e. the system of preparation and presentation of financial statements (Fletcher, 2002). "Factors determining the development of accounting at the national level also contribute to accounting diversity at the international level (Saudagaran, 2004)." This is confirmed by the generally accepted conclusion of Adhikari and Tondkar: "Accounting and reporting standards and practices are not developed in a vacuum, but reflect the specific environment in which they are developing (Haskins, Ferris, \& Selling, 2000)." Starting from the above statements, the research objective in this paper is to indicate to the IASB.s project of IAS/IFRS review, highlighting the problems faced by national enterprises in their implementation, especially when it comes to small and medium-sized enterprises. In doing so, it highlights the accounting practice and experience in certain countries, especially from the neighbouring and comparable environment of Serbia. This is particularly related to those countries that also had an obligation to implement the IFRSs, prescribed by domestic legislation, and in which the general content of the financial statements was under the significant influence of the IAS 1 and EEC Directive IV (1978) and now the EU Directive 34 (2013).

\section{THE IASB-S PROJECT OF THE INTERNATIONAL FINANCIAL REPORTING STANDARDS}

Making economic decisions by enterprises in different markets of goods, services and capital, as well as many others, is not possible without reliable, transparent and comparable accounting information, expressed through certain financial statements. The International Financial Reporting Standards, i.e., the International Accounting Standards and related documents creation and approval, such as the Framework for financial statements and other documents preparation and presentation, are under the jurisdiction of the International Accounting Standards Board (IASB) in Great Britain. According to the IASB, the purpose of financial statements is to offer the information on the financial results and the financial position of an entity useful to a wide range of users so that they could evaluate management quality shown by the entity management, and enable them to make economic decisions. The purpose of financial statement submission can usually be met through attention directly to the needs of the existing and potential investors and other external information users. Such external users need the information to evaluate the entity's ability to increase revenue and on that basis, to evaluate positive financial results. According to Anđelković \& Vujić (2019), "the process of value creation is not based on the traditional formula where it begins with input and ends with output". However, although financial statements lack all the information necessary for the users, they still provide the framework within which information users can compare specific information gained from other sources (Kothari \& Barone, 2012). The International Federation of Accountants (IFAC) has an important role in this process, determining certain accounting principles through standards in the information quality and user interest contexts, thus harmonising accounting to a large extent, i.e., financial statement preparation and presentation system. When it comes to professional regulation activities definition, we should also state, according to Barth, Landsman, Lang \& Williams (2012), generally accepted accounting principles - US GAPP. The Association of Accountants and Auditors of Serbia was among the first to recognize the necessity for standardization and harmonization in accounting in the Republic of Serbia; as IFAC full member, it reached the decision and declared the direct implementation of the International Accounting Standards at the end of December 1998, along with the expected legislative support.

In May 2002, the IASB published the final Preface to the International Financial Reporting Standards, with the following basic goals (Stefanović, 2003): 
- to develop a set of high-quality, comprehensible and applicable global accounting standards with the high-quality, transparent and comparable information in financial reports as a result, to help the participants in world capital markets and other users in reaching economic decisions;

- to promote the use and mandatory implementation of these standards;

- to take an active part in finding a solution to the national accounting standards and the IFRS convergence along with the national standard-makers.

The decision reached by the IASB and the Financial Accounting Standards Board (FASB) in the United States of America is of particular importance in the context of the above stated goals, which establishes their mutual cooperation for a higher degree of conformity within the United States between Generally Accepted Accounting Principles (US GAAP) and the International Financial Reporting Standards (IFRS), formerly known as the International Accounting Standards (IAS). The successful outcome of this harmonisation will significantly improve global capital market efficiency: the costs would be reduced, report comparability improved as well as corporate management (Ivkov, 2014). New International Financial Reporting Standards should offer a key contribution to more correct and accurate financial report compilation in the future, in order to create prerequisites for reaching more reliable financial and business decisions (Dragojević, Miljević \& Milojević, 2012).

The International Accounting Standards can be applied in various ways. The in IAS/IFRS application is as follows (Klikovac, 2008):

- IAS/IFRS are used as the national standards in the countries where there are no national accounting standards, i. e., financial reporting standards, or in the countries that have ceased to implement them.

- IAS/IFRS are used as the international benchmark in many industrial countries and the growing market countries developing their standards.

- IAS/IFRS are accepted by numerous stock exchanges and regulators allowing foreign or domestic companies to submit financial statements compiled according to the IAS/IFRS.

- IAS/IFRS have been recognized by the European Commission and many other international bodies.

When it comes to the national Law on Accounting that contributed to financial reporting harmonisation, apart from later adopted IAS/IFRS, the Law adopted in 1996 had particular importance (Stevanović \& Ilić, 1996), because it was based on the European Union directives and other International Accounting Standards. The aforementioned law represents a further step in creating assumptions for financial reporting quality improvement in relation to the previous Laws from 1989 and 1990. According to the aforementioned law (1996), financial reporting harmonization should have left enough possibilities for national professional regulation. Some provisions of the former law were completed starting from the provisions of the fourth and seventh directives as well as the International Accounting Standards. For example, it refers to the mandatory compilation of the cash flows statements in addition to the balance sheet and income statement, as well as the parent company liability to compile and present an additional report annexe, in addition to the consolidated balance sheet and income statement. The income is a form of the result and regular company financial reports, and the contents of the balance sheet, income statement and cash flows statements are completely adapted to the demands in form and content stated in the EU directives and the International Accounting Standards (Škarić \& Dendić, 2005). According to the above-mentioned authors, the adoption of the Law on Accounting and Auditing (2002) was a condition for IAS/IFRS acceptance in financial report position evaluation. Several changes in this law influenced its more complete harmonisation with IAS/IFRS. It is stated there that "legal entities and entrepreneurs are obliged 
to manage bookkeeping, financial report compilation and presentation according to the accounting principles defined within the IAS. The IAS will be applied for financial report recognition, evaluation and presentation."

The adoption of Law on Accounting and Auditing (2002) continued the efforts referring to the financial report harmonisation. However, a lot of issues regulated by the former Law on Accounting from 1996 were not regulated by the law on Accounting and Auditing valid at the time, or at least they were not regulated in the appropriate manner. In that context and according to the paper by Vukelić (2010), we can state that the historical aspects of the regulations are important for the legal regulations in the area of financial reporting.

Škarić and Dendić (2005) consider these as the most important weaknesses of the Law from 2002:

- the request that the IAS has to be applied in all companies, regardless of size;

- the division of the jurisdiction of the state and professional organisations that is not distinct;

- the non-existent specific mechanism for the provision of high-quality translation for the IAS as the normative foundation for financial report compilation;

- the deadline provided for the IAS application was not appropriate.

The adoption of the Law on Accounting and Auditing in 2006 as well as in 2009 continues the efforts to organise the accounting profession and the achievement of full harmonisation with the international accounting regulations. These laws enabled the establishment of institutions referring to the Chamber of Authorized Auditors and National Commission for Accounting. The provisions of these laws related to the IAS application should enable the compilation of the compatible financial statements. Faced with the new financial reporting model based on the IAS/IFRS, the attention of our companies, primarily their accountants, was mostly attracted by IFRS 1 (The International Financial Reporting Standards, 2009). This is the consequence of the fact that the IFRS 1 establishes the procedures the companies must follow during the initial application of the IFRS as the foundation for the preparation of their financial statements. In the course of the practical application of these procedures, the subjects are faced with the challenge of retrospective application combination with certain exceptions, and it makes the initial IFRS application rather complex.

From the point that financial report quality can be provided in accepting the IAS as the national accounting standards, the aforementioned Laws on Accounting and Auditing imposed their application as mandatory. The Republic of Serbia accepted the International Financing Reporting Standards as the only framework for financial reporting in all companies. Only small taxpayers are exempted from this obligation because they can decide not to apply the IFRS if their securities are not traded in the organised securities market. On the basis of the research conducted in the previous 18 years of the twenty-first century, when a need for harmonization in accounting appeared as a result of the growing globalization in the world of business, the leading authors in the international accounting reached the results indicating the existence of a number of causes for the international differences in financial reporting. Some of the most common in the references are (Alexander, Britton \& Jorissen, 2005): 1) legal system, 2) funding sources, 3) the relation between financial and tax reporting, 4) the influence of national accounting profession, 5) inflation levels, 6) microeconomic theory, 7) business development and 8) historical coincidence (accidence). The differences mentioned above question the possibility of financial reporting comparison between entities from various countries. Compatibility problem is particularly manifested in foreign financial report analysis necessary for making investment and credit decisions. Therefore, the users should carefully identify the causes of the differences in the analysis of these reports, i. e., they have to determine whether they come from the accounting measurement differences, basic environment factors (primarily social, political, legal, economic) or whether they are caused by the true differences of the attributes measured. Based on this, we can state that our country unilaterally accepted the 
International financial reporting standards as the only framework for financial reporting for all companies (small taxpayers exempted) when it adopted the new Law on Accounting (2013; 2018), disregarding the differences in the accounting measurements, basic environment factors as well as company size and structure. This kind of accounting system design in a country national accounting system, had a negative effect on the financial information quality for their users (especially investors and creditors).

Based on these statements, we can say that financial reporting quality improvement perspectives also depend on the consideration of the basic factors influencing financial reporting in each country, especially if it aspires to a certain union of the countries, as is the case with our country. However, in this case, the differences influencing financial reporting cannot be minimised to such an extent that they result in "the unique set of the International Financial Reporting Standards". Also, the differences in company size structure, the business they deal in, whether the company securities are rated on the stock exchange or not, as well as other specific points, should define a commitment to apply the IAS/IFRS.

\section{THE IASB PROJECT OF THE IFRS FOR SMALL AND MEDIUM-SIZED ENTERPRISES}

The adoption of the new Law on Accounting (2018) continued the efforts towards the achievement of financial reporting total harmonisation. There is a special International Financial Reporting Standard for Small and Medium-sized entities - IFRS for SMEs, approved by the International Accounting Standards Board (IASB) for financial reporting position recognition, evaluation, presentation and disclosure. In doing so, there is still a possibility for small entities to decide in favour of IFRS application related to large entities. In relation to small and medium entities, the new Law on Accounting, unlike the previous Law on Accounting and Auditing, specifies the special IFRS application for large entities that have an obligation to compile consolidated financial reports, as well as for public companies.

Regular annual financial report for entities applying the IFRS, i. e. IFRS for SMEs, includes, according to the Law on Accounting $(2013 ; 2018)$ :

1. Balance sheet, representing an overview of assets, liabilities and capital of a legal entity on a given day;

2. Income Statement, representing an overview of revenues, expenditures and business results incurred in a given period;

3. The statement on the rest of the result, which consists of income and expense items (reclassifications due to correction included), not recognised in the balance sheet as required or allowed according to other IFRS. The components of this result consist of items recognized within capital according to certain IFRS requirements;

4. Capital changes statement, providing information on the changes in legal entity capital during the reporting period;

5. Cash flow statement, providing information on cash inflow and outflow as well as cash equivalents during the reporting period;

6. Notes to the financial statements, containing descriptions or breakdowns of the items disclosed in the aforementioned reports, the accounting policies applied, as well as information on items that did not qualify for recognition in these reports, and they are significant for the assessment of the financial position and legal entity performance, as well as other information in accordance with IFRS requirements.

According to the Financial Reporting Committee decision, a draft of the Croatian accounting standards was started for small and medium entities in the Republic of Croatia. The accounting standards were based on the IFRS, but they also accepted some specific points based on the small and medium-sized enterprises needs in Croatia. Based on the Financial Reporting Standards Committee decision from 2006, balance sheet, as well as profit and loss account is 
stipulated by law, in form and content compliant with the fourth EU directive, as well as the former Law on Accounting. The form and content of abbreviated balance sheet and profit and loss account is stipulated for the companies classified as small enterprises according to the aforementioned Law on Accounting. Consequently, small enterprises are only required to compile an abridged balance sheet, profit and loss account, but not cash flow statement or capital change statement as previously stated in our professional regulations. "According to the Law on Accounting from January 2008, the implementation of the national Croatian financial reporting standards (CFRS) was introduced. According to these standards, small and mediumsized enterprises are required to implement the IFRS only if their securities are quoted in the securities market or preparing to be introduced into the Croatian market. Otherwise, small and medium-sized enterprises are not required to implement IFRS (Klikovac, 2008). The stated approach is in accordance with the statements from the first part of this paper related to the financial reporting harmonization, the creation of our national professional accounting regulations, with considerations of the international differences present in financial reporting (legal system, funding sources, financial and tax reporting relations, the influence of the national accounting profession). In the absence of expert criticism and professional normative regulation ethics, it was the easiest to accept the IAS/IFRS implementation automatically and completely for financial reporting purposes. Also, we should take care of our close environment in relation to the European Union, and consider the professional accounting regulation of its members as well as the relation to the IAS/IFRS. If we consider the case of Croatia in this context, the basic Stabilization and association agreement between Croatia and the European Union anticipates Croatia's commitment to adjust its legislation to the EU regulations within the deadlines. Likewise, the National program of Croatia for EU accession from 2005 accepted the commitment to adopt the EU legislation in accounting. Thereby, it was necessary to harmonize the Law on Accounting with the fourth and seventh directive, as well as the EU provisions regulating the accounting system in the European Union. The new Law on Accounting was created according to the EU provisions, and therefore Croatia, as well as most of the EU countries, does not require the mandatory implementation of IFRS for all companies, but only for those large listed companies or those preparing for listing. The rest of the companies in Croatia are given the opportunity to choose whether to implement the IFRS or any other standards approved by the Financial Reporting Standards Committee.

The fact remains that the national accounting standards differ in certain segments in some of the countries. In other words, not all companies have an obligation to implement international accounting regulations. Thus, for example, only the companies with the securities quoted at the American Stock Exchange have to compile their financial statements according to the US GAAP. On the other hand, mandatory implementation of the IAS/IFRS is explained differently in the EU countries, while mandatory IAS/IFRS implementation refers to all the companies in our country, although it is structured in a different way depending on the company size (Dmitrović - Šaponja, Milutinović \& Šijan, 2010). Mandatory implementation of the IAS/IFRS is defined for large companies separately from the implementation for small and medium-sized enterprises. In doing so, the burden of regulations and financial statement simplification for small and medium-sized enterprises was not considered, especially when it comes to micro subjects and entrepreneurs. The experiences about financial statement quality improvement for small and medium-sized enterprises have already existed when we speak about the European Union. In fact, previous accounting directives: EEC Directive IV (1978), and EEC Directive VII (1983), for small and medium-sized enterprises, and particularly for micro subjects, often represented great regulatory burdens. An appropriate audit of the accounting directives was carried out, and there were significant simplifications in financial statements structure for small and medium-sized enterprises in new EU Directive 34 (2013). The focus of special attention in terms of regulatory burden reduction was on micro subjects. Harmonisation of legal regulations with professional regulations, i.e. EU Directive 34 (2013) and the International Financial Reporting Standards, is particularly emphasised on the path to financial reporting quality improvement. On that basis, national accounting regulations that strive and 
participate in the standardisation process become an active participant in the modern, international financial reporting system.

The key role in the financial reporting harmonisation process at the international level belongs to the European Union, which has a significant impact on the International Accounting Standards Board (IASB). It strives to adjust the IFRS to its interests and the interests of the EU member countries with its influence (Anđelković, 2018). The first European attempt to harmonise financial reporting at the international level was, as mentioned, through the EEC Directive IV (1978) and EEC Directive VII (1983) introduction. In June 2013, a new EU Directive 34 was adopted, on annual financial statements. This newly adopted EU Directive 34 (2013) replaces the fourth and seventh Directives through their integration, with certain changes and additions. A separate part of the EU Directive 34 (2013) refers to large companies with the quotes at the Stock Exchange as well as the consolidated financial statements. IAS/IFRS implementation is prescribed for the listed companies. Most of the EU members allow (do not prescribe) IAS/IFRS implementation in the course of the compilation of consolidated financial statements for the companies not quoted at the Stock Exchange. The Directive requires consolidation for the group of companies over a certain size, and the audit based on this requirement.

Presented balance sheets in terms of form (in horizontal and vertical forms) and according to the assets and liabilities structure have been framed in order to fit all companies, regardless of their legal form and size. One of the balance sheet models can be used by large, medium-sized and small enterprises. When it comes to small and medium-sized enterprises, there are certain simplifications. Small enterprises compile their balance sheets according to the same scheme, but they only show the positions marked by letters and Roman numerals. Further analysis, denoted in Arabic numbers, does not refer to these companies. Directive 34 pays special attention to the recognition rules in the context of financial reporting quality improvement. The main methodology of business events evidence and evaluation is based on the historical cost principle, i. e. price (production costs) or purchase value in order to provide information reliability in financial statements. However, the Directive allows the national legal systems to use alternative evaluation methods, as in the case of a fair value method. The basic goal of EU Directive 34 (2013) implementation is to increase financial information comparability and transparency on the basis of the aforementioned statements and other normative scopes; in order to achieve that, it is necessary for the EU member states to provide a common framework for balance position recognition, their measurements and financial statement presentation (Andjelković, 2018). Financial statements comparability as one of the means of communication among the member state companies is increasing, bearing in mind its significance for their users. These are only some of the examples, not the only ones, indicating the differences among the national regulations of certain countries. All that, along with the above-mentioned issues, indicates that the process of financial reporting harmonisation at the global level is difficult to achieve, considering the companies not quoted at the market, especially when it comes to mediumsized and small enterprises. But surely, as ensues from the discussion on the EU Directives, in some parts of the world "the language of accounting will be changed". In this context, Martic (2013) states that Extensible Business Reporting Language - XBRL appeared at the end of the 1990s, used for structural business information exchange via Web, widely accepted in the international accounting community, promising a revolution in financial reporting and business information exchange. XBRL standard offers a wide range of advantages in business information collection, storage and processing, as well as financial statements compilation and disclosure.

In one part of the paper on "Harmonization of Serbian accounting standards with the EU standards", Vukelić, Đuričin \& Belopavlović (2011) state that "The development of the global economy imposes a need for the harmonisation of financial reporting. In order to make relevant decisions, capital investors demand a unique system of financial reporting at the global level and also expect that domestic competent institutions will create such a regulatory framework which will elevate the domestic financial reporting to a higher level. Hence they have expectations in view of legal solutions, which would provide conditions for the standardisation and compliance 
with the best solutions in the countries with developed market economies". In connection to this, Đuričin (2012) illustrates the same issue in a separate part of the paper, related to the national accounting standards harmonisation with the EU standards. In this context, the critical review of the national financial reporting is indicated as well as the recommendations for the national accounting regulations improvement. In the context of the public companies functioning and characteristics, bearing in mind the specific environment, Milojević (2018) also raises the question of financial reporting quality improvement.

Finally, we can state that in addition to various solutions in terms of IAS/IFRS implementation (from full acceptance of the IAS/IFRS for all the companies to the exclusive implementation of their own standards), generally speaking, we can state that the IAS/IFRS are accepted, as a rule, in the companies where securities are publicly traded with, while the others implement the national standards. According to this, the American Securities and Exchange Commission (SEC) requires foreign companies with the securities listed in the stock exchange to present their financial statements periodically. Nevertheless, the reporting requirements for foreign companies are essentially the same as the ones set for national companies. The foreign companies may present secondary financial statements compiled based on the US GAAP. Thereby, the SEC requires the Canadian companies procuring capital in the US capital market to publish any deviation from "the generally accepted accounting principles" in the USA, and to present the financial effect of these deviations on the property, financial structure and success of the company. According to Barth, Landsman, Lang, \& Williams (2012), the question of accounting standards comparability based on IFRS and US GAAP arises in this context. The aforementioned discussion in this paper results in the statement that the process of global financial reporting harmonisation refers primarily to large companies that are listed on the stock exchange.

\section{CONCLUSION}

The current tendencies of the national accounting regulations show that, in addition to the IAS/IFRS, the US generally accepted accounting principles (GAAPs) and the EU Directive 34 (2013) represent the key segments of professional regulation. Most countries that have their national accounting regulations align their accounting rules in the most important aspects of these regulations. Hereby, not all enterprises have an obligation to implement international accounting regulations. The European Union plays a key role in the process of harmonising financial reporting at the international level, and it also has a significant impact on the International Accounting Standards Board (IASB). The newly adopted EU Directive 34 relating to the annual financial statements particularly contributes to this.

The Republic of Serbia should have its national accounting regulations, its own accounting rules which, as we strive to the European Union accession, must be harmonised in the most important issues, in the first place with EU Directive 34 (2013). The Directive 34 (2013) sets out the form and content of the financial statements, the rules for the preparation of financial statements of large, and especially medium and small-sized enterprises. It also regulates other issues that seek to adopt the IFRS to the interests of the European Union and the national interests of its member states.

The implementation of the IAS/IFRS may be mandatory for large enterprises and listed enterprises. Likewise, the implementation of the IAS/IFRS for small and medium-sized enterprises often represents a large regulatory burden. From this aspect, an appropriate review of the IAS/IFRS should be carried out and a significant approximation of the regulatory framework to the interests of small and medium-sized enterprises. In this case, the implementation of the IAS/IFRS may be mandatory for medium-sized enterprises whose securities are quoted on the stock exchange. For other enterprises, the implementation of the IFRS would be permitted, but not prescribed. This would leave the possibility to create special 
national standards for small and medium-sized enterprises. The process of global harmonisation of financial reporting when it comes to the unlisted enterprises and especially when it comes to small and medium-sized enterprises can be relatively difficult to achieve. Special attention, when it comes to professional accounting regulations, should be directed at micro entities, given their importance and contribution to the economic development of our country and the increase of employment rate.

\section{REFERENCES}

Alexander, D., Britton A., \& Jorissen, A. (2005). International Financial Reporting and Analysis, Second Edition, Thomson, pp. 22.

Anđelković, D. (2018). Accounting with analysis of financial statements: International approach, University of Novi Sad Economic Academy, pp. 170.

Anđelković, D., \& Vujić, M. (2019). The impact of service users' satisfaction on financial performance of hotel enterprises; The Fourth International Scientific Conference: Tourism in function of development of the Republic of Serbia, University of Kragujevac, Faculty of Hotel Management and Tourism in Vrnjačka Banja, Serbia, May 30th - June 1.

Barth, E. M., Landsman, R. W., Lang, M., \& Williams, C. (2012). Are IFRS and US GAPP-based accounting amounts comparable?, Journal of Accounting and Economics, Volume 54, 68-93, Elsevier B.V.

Đuričin, S. (2012). Business analysis and the possibilities for companies to exit the loss zone, Institute of Economic Sciences, Belgrade, pp. 34-45.

Dmitrović Šaponja, Lj., Milutinović, S. \& Šijan, G. (2010). Harmonization of Financial Reporting in Terms of Globalization, 8th International Symposium of Management SIM 2005 „Management of Organizations in the Context of Globalization and European Integration", Timisoara, Romania, pp. 87.

EEC Directive IV (1978). EEC Official Journal, Brussels.

EEC Directive VII (1983). EEC Official Journal, Brussels.

EU Directive 34 (2013). EU Official Journal, 182/19, Brussels.

Dragojević, D., Miljević, T. \& Milojević, M. (2012). The new key IFRS, Socioeconomica - The Scientific Journal for Theory and Practice of Socioeconomic Development, Vol. 1, N0 2, pp. 203.

Fletcher, G. (2002). International Accounting Standards - Past, Present and Future, AFP Exchange, July/August.

Haskins, E. M., Ferris, R. K., \& Selling, I. Th. (2000). International Financial Reporting and Analysis: A Contextual Emphasis, Second Edition, McGraw-Hill, International Editions, p. 3, according to Stefanovic, R. Bogicevic, J. (2006); Understanding the international differences in financial reporting. A monograph: Corporate management in transition, Faculty of Economics, Kragujevac, pp. 40.

Ivkov, D. (2014). Creating financial reports in the function of trade company business performances analysis, doctoral dissertation, Faculty of Economics in Subotica, University of Novi Sad, pp. 129.

Kothari, J. \& Barone, E. (2012). Financial accounting: An International Approach, Data Status, Beograd.

Klikovac, A. (2008). Financial reporting in the European Union, Mate, Zagreb, pp. 83, 89.

Martić, V. (2013). XBRL application for financial reporting quality improvement, 44 Symposium, Accounting regulatory environment: the incentive or limitation to the economic growth, Proceedings, Association of Accountants and Auditors of Serbia.

Milojević, M. (2018). The State of Public Enterprise Financial Reporting in Serbia, Economic Analysis, Vol. 51, No 3-4, Institute of Economic Sciences, Belgrade, pp. 105-114.

Saudagaran, M. Sh. (2004). International Accounting: A User Perspective, Second Edition, Thomson. 
Stefanović, R. (2003). The International financial reporting standards: the essence and initial implementation, Banking, no. 11/12, Belgrade.

Stevanović, N. \& Ilić, G. (1996). The Law on Accounting with comments, Association of Accountants and Auditors of Serbia, Foreword.

Škarić, K. \& Dendić, D. (2005). Financial reporting - the achievements and experiences, 36th Symposium: accounting and business finance in modern business - situation and perspectives, Association of Accountants and Auditors of Serbia, Zlatibor, pp. 26 - 31.

The International Financial Reporting Standards 2009. Association of Accountants and Auditors of Serbia, Belgrade.

The Law on Accounting, Official Gazette of SFRY nos. 12 and 35/1989, no. 3/1990.

The Law on Accounting and Auditing, Official Gazette FRY, no. 71/2002.

The Law on Accounting and Auditing, Official Gazette of the Republic of Serbia, nos. 46/2006 and $111 / 2009$.

The Law on Accounting, Official Gazette of the Republic of Serbia, nos. 62/2013, 30/2018.

Vukelić, G. (2010). Professional accounting regulations and financial reporting, 41 ${ }^{\text {st }}$ Symposium: the possibilities and limitations of the accounting profession development in Serbia, the Association of Accountants and Auditors of Serbia, Zlatibor, p. 53.

Vukelić, G., Đuričin, S. \& Belopavlović, G. (2011). Harmonization of Serbian accounting standards with the EU standards, in the publication: Serbia and the European Union: Economic, Coimbra, Portugal, the Institute of Economic Sciences, Belgrade Baking Academy Faculty of Banking, Insurance and Finance, pp. 92-104.

Article history: $\quad$ Received: April 9, 2019

Accepted: June 3, 2019 